\title{
Site-specific binding of wild-type p53 to cellular DNA is inhibited by SV40 $T$ antigen and mutant $\mathrm{p} 53$
}

\author{
Jill Bargonetti, Inga Reynisdóttir, Paula N. Friedman, and Carol Prives ${ }^{1}$ \\ Department of Biological Sciences, Columbia University, New York, New York 10027 USA
}

\begin{abstract}
Wild-type p53 protein was shown to bind specifically to DNA sequences within SV40 (Bargonetti et al. 1991), the human ribosomal gene cluster (RGC) (Kern et al. 1991a), and the murine muscle creatine kinase gene (MCK) (Zambetti et al. 1992). However, a direct comparison of these three sites was not performed. Here we demonstrate, by filter binding and gel mobility-shift assays, that wild-type p53 binds with similar affinities to MCK and RGC sites but less tightly to the SV40 site. We examined the effects of two candidate regulators of p53 function, SV40 large T antigen and oncogenic mutant p53, on the binding of wild-type p53 to RGC DNA. We show that wild-type $T$ antigen prevents $p 53$ from binding to the RGC site under all conditions tested. Moreover, two temperature-sensitive mutant SV40 $\mathrm{T}$ antigens, which fail to transform cells at the nonpermissive temperature, prevent p53 from binding to the RGC site at the permissive, but not at the restrictive, temperature. The ability of complexes containing wild-type $p 53$ and tumor-derived mutant p53 proteins to bind to RGC DNA varies according to the position of the mutation. Complexes containing wild-type and either his 175 or his 273 mutant p53 proteins are completely unable to bind to the RGC DNA sequence. Interestingly, a complex containing wild-type p53 and the trp248 mutant p53 characteristic of Li-Fraumeni syndrome patients displays nearly wild-type levels of binding. Perhaps this mutant allele can be tolerated in these individuals because the wild-type mutant p53 complex maintains the ability to bind to DNA. Our data indicate that the oncogenic potential of both $T$ antigen and some mutant p53 proteins is the result of their ability to block binding of wild-type p53 to DNA.
\end{abstract}

[Key Words: Wild-type p53 protein; mutant p53; site-specific binding; SV40 T antigen]

Received June 3, 1992; revised version accepted July 21, 1992.

Mutations in the p53 tumor suppressor gene are the most frequently observed genetic lesion found in human cancer (Nigro et al. 1989; for review, see Hollstein et al. 1991). A high proportion of tumors from cancer patients express a single mutant $\mathrm{p} 53$ allele. This phenomenon is not confined to human cells; mutant forms of p53 often occur in mouse erythroleukemias induced by Friend virus (Mowat et al. 1985; Chow et al. 1987; Munroe et al. 1987), and mice engineered to express no p53 whatsoever display strong susceptibility to tumor formation (Donehower et al. 1992). On the basis of these and other types of observations, it is an accepted premise that the product of the wild-type p53 gene functions as a tumor suppressor protein that may regulate progression through the cell cycle (for review, see Lane and Benchimol 1990; Levine et al. 1991). In support of the evidence that p53 may normally maintain the quiescent state is the fact that three different oncogenic DNA tumor virusesSV40, adenovirus, and human papillomavirus-each encode gene products that bind to p53 (for review, see Levine and Momand 1990).

\footnotetext{
${ }^{1}$ Corresponding author.
}

Although the mechanism by which $\mathrm{p} 53$ operates is not yet elucidated, a number of biochemical and genetic characteristics of the 553 protein have been determined. Wild-type p53 is a phosphoprotein, the nuclear localization of which is controlled in a cell-cycle-dependent fashion and which is apparently essential for the normal activity of the protein (Addison et al. 1990; Shaulsky et al. 1991). Sequences that confer strong transcriptional activation properties to a GAL4 DNA-binding domain are located within the amino terminus of p53 (Fields and Jang 1990; O'Rourke et al. 1990; Raycroft et al. 1990; Unger et al. 1992). Furthermore, several reports have provided evidence that in cell transfection assays, p53 regulates expression from various cellular promoters leading to either stimulatory (Weintraub et al. 1991) or inhibitory (Ginsberg et al. 1991; Mercer et al. 1991; Santhanam et al. 1991; Chin et al. 1992) effects. Together, these observations suggest that p53 may exert its growth control functions at the level of DNA-protein interactions and/or protein-protein interactions. The p53 protein, which was shown to exhibit nonspecific DNA-binding properties (Kern et al. 1991b), also displays sequence-specific interactions with DNA. Wild-type, 
but not mutant, forms of $\mathrm{p} 53$ were shown to bind specifically to a region of the SV40 viral genome (Bargonetti et al. 1991) and the human ribosomal gene cluster (RGC) (Kern et al. 1991a). More recently, p53 was also shown to bind to a sequence within the $5^{\prime}$-flanking region of the murine muscle creatine kinase (MCK) gene (Zambetti et al. 1992). In addition to the sites above that are within the vicinity of recognized genes, several as yet unidentified human DNA-binding sites for p53 have been isolated and these have led to a suggested consensus-binding sequence (El-Deiry et al. 1992).

All tumor-derived mutant p53 proteins tested to date exhibit an inability to bind either nonspecifically /Kern et al. 1991b) or specifically to viral or cellular DNA (Bargonetti et al. 1991; Kern et al. 1991a). Therefore, DNA binding is probably central to the function of $\mathrm{p} 53$ in regulating cell growth. Accordingly, in this study we have undertaken a comparative analysis of the binding of p53 to the SV40, RGC, and MCK sites. Previous studies investigating the specific DNA-binding properties of $\mathrm{p} 53$, employed either immunobinding and methylation interference (Kern et al. 1991a) or DNase I footprinting assays (Bargonetti et al. 1991; Zambetti et al. 1992). Here, using both gel mobility-shift assays, nitrocellulose filter binding, and DNase I protection to analyze the interactions of p53 with these sites, we have noted both common features and also differences in affinity and types of p53 protein-DNA complexes among the three sites.

Owing to the implicit importance of p53 binding to DNA, it was also of interest to examine ways in which this property of p53 might be regulated. We examined the effects of two types of proteins that have been postulated to inhibit the normal function of wild-type p53 in cells. First, as SV40 T antigen forms a tight complex with p53 in both virally infected and transformed cells (for review, see Levine and Momand 1990), we examined the effects of wild-type and conditional mutant forms of $\mathrm{T}$ antigen on the binding of $\mathrm{p} 53$ to cellular DNA. Second, as mutant p53 is capable of functioning in cooperation assays to transform cells (Hinds et al. 1989; Halevy et al. 1990; Hinds et al. 1990; Hicks et al. 1991), we tested the ability of several tumor-derived $\mathrm{p} 53$ proteins to regulate the DNA-binding properties of wild-type $\mathrm{p} 53$. We have demonstrated that $\mathrm{T}$ antigen and some, but not all, mutant $\mathrm{p} 53$ proteins strongly repress the ability of wild-type p53 to bind site specifically to cellular DNA. These observations highlight the importance of the DNA-binding function of p53 and should provide impetus to identify cellular genes whose activity is regulated by the DNAbinding capacity of wild-type p53.

\section{Results}

Human p53 binds similarly to oligonucleotides containing DNA-binding sequences from the RGC and the MCK gene

We compared the ability of immunopurified wild-type human p53 to bind to the following double-stranded oligonucleotides, the sequences of which are shown in Ma- terials and methods: (1) the RGC-binding sequence (RGC-W); (2) a mutated RGC sequence designed for minimal p53-binding affinity (RGC-M) (Kern et al. 1991a); (3) the MCK-binding sequence (MCK); and (4) the SV40 DNA-binding sequence (SV40). When an electrophoretic mobility-shift assay (EMSA) was used to analyze the relative binding affinity of immunopurified $\mathrm{p} 53$ for the four different oligonucleotides, multiple discrete proteinDNA complexes were resolved (Figs. 1 and 2). The multiple forms observed that are referred to as $1,2,3$, and 4 most likely correspond to oligomeric forms of p53 that are detected by nondenaturing protein PAGE, with form 1 being the $\mathrm{p} 53$ tetramer and the remaining forms, larger oligomers (see Discussion). Form 3 actually contains two distinct but closely migrating species, and we have designated form 4 as material that is too large to enter the gel.

The relative binding affinity of $\mathrm{p} 53$ for the RGC-M and RGC-W oligonucleotide was examined by EMSA in the presence of increasing amounts of poly[d(I-C)] (Fig. 1A). Analysis by PhosphorImaging with Image-Quant software (Molecular Dynamics) and the values obtained are presented in Figure 1B. At all levels of poly[d(I-C)] tested, p53 had a higher affinity for RGC-W as compared with the nonspecific oligonucleotide (RGC-M). In addition, p53 forms 3 and 4 showed virtually no binding to the nonspecific oligonucleotide (Fig. 1A). The superior binding of p53 to RGC-W was demonstrated further by a second experiment comparing competition by unlabeled RGC-W and RGC-M oligonucleotides (Fig. 1C, cf. lanes 4 and 5 with 6 and 7). Confirming that p53 was present in these complexes, the addition of the human p53-specific monoclonal antibody PAb 1801 caused a massive "supershift" of the protein-DNA complexes (Fig, 1C, lanes $8-10)$.

The relative binding of $\mathrm{p} 53$ to the RGC-W and MCK oligonucleotides was then compared (Fig. 2A). An excess of unlabeled RGC-M was unable to compete for the binding of p53 to either labeled MCK or RGC-W (Fig. 2A, lanes 3,8). However, binding to both radiolabeled MCK and RGC-W oligonucleotides was competed efficiently with an excess of unlabeled RGC-W or MCK oligonucleotides (Fig. 2A, lanes 4,5,9,10). The overall affinity of p53 for both sites is comparable as determined both by EMSA and by nitrocellulose filter-binding assays (L. Jayaraman, J. Bargonetti, and C. Prives, unpubl.). However, qualitative differences in the shifted DNA-protein complexes were observed when no competitor DNA was added (Fig. 2A, lanes 2,7). Notably, the ratio of forms 2,3 , and 4 to form 1 was greater with MCK than with RGC-W.

We also compared the binding of p53 to the RGC-W and SV40 oligonucleotides by EMSA and quantitated the results by PhosphorImaging analysis (Fig. 2B). With an excess of unlabeled RGC-M, the amount of both RGC-W and SV40 oligonucleotides shifted was $\sim 65 \%$, as demonstrated by PhosphorImaging (Fig. 2B, lanes 4,11). An excess of unlabeled SV40 oligonucleotide was an efficient competitor (lanes $5,6,12,13$ ) but not as efficient as similar quantities of the RGC-W oligonucleotide (lanes $7,8,14,15)$. When competing with excess SV40 oligonu- 

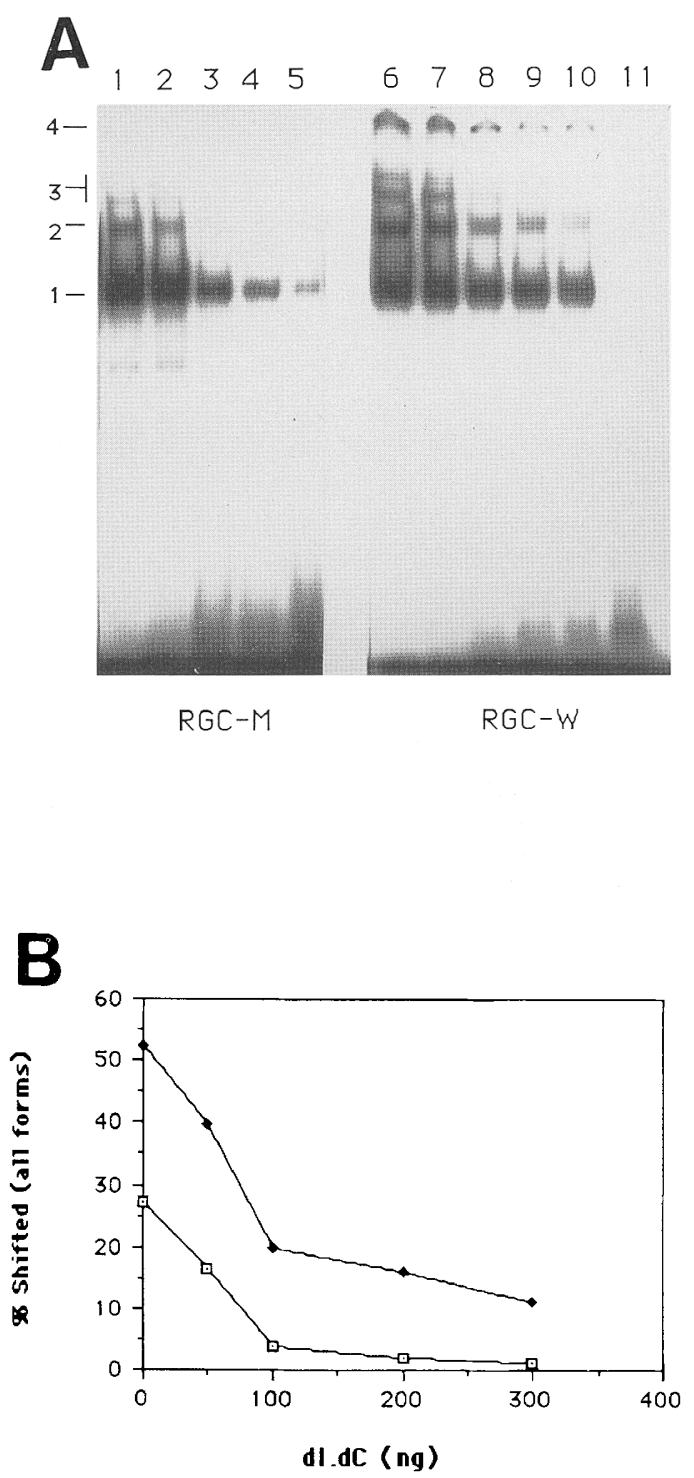

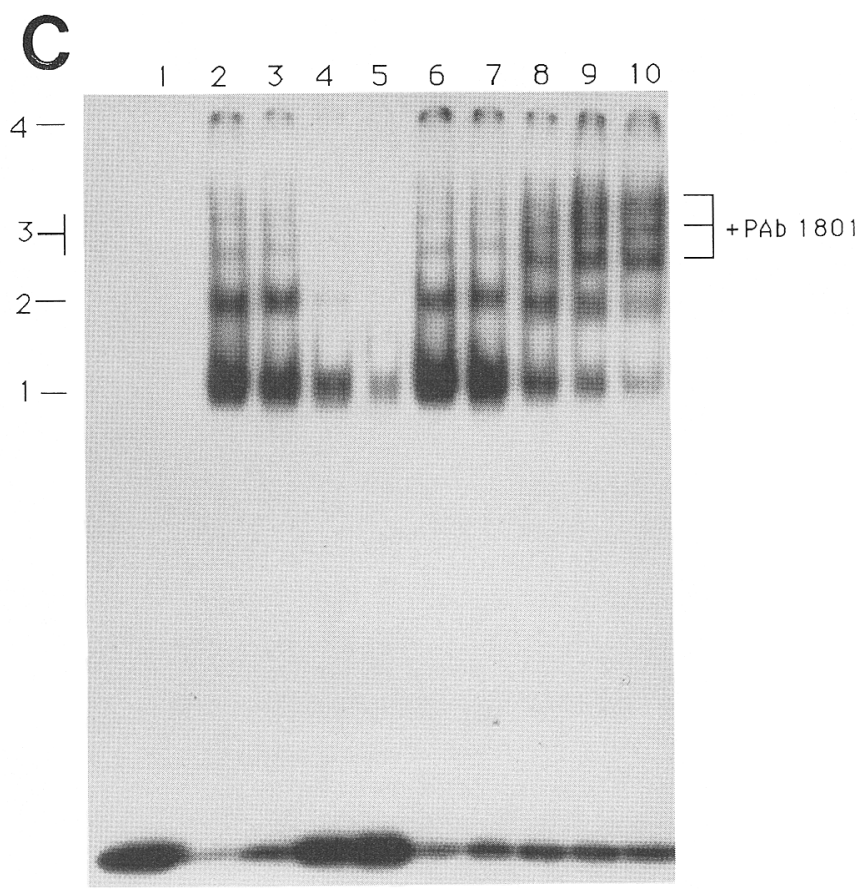

Figure 1. Multiple forms of p53 bind preferentially to RGC-W oligonucleotides. (A) EMSA competition analyses using 1.5 pmole of either radiolabeled RGC-M (lanes 1-5) or RGC-W (lanes 6-11) and increasing amounts of poly[d(IC)]. Reaction mixtures contained wild-type human p53 (1 $\mu \mathrm{g})$ with 0 (lanes 1,6$)$, 50 (lanes 2,7), 100 (lanes 3,8), 200 (lanes 4,9), or 300 (lanes 5,10) ng of poly[d(IC)]. A sample in which no p53 protein was added is shown in lane 11. $(B)$ Graphic representation of results shown in $A$ as quantitated by Phosphorimager using Image-Quant software. $(\mid)$ RGC-W; $(\square)$ RGC-M. (C) EMSA competition analysis using 1.5 pmole of radiolabeled RGC-W and $1 \mu \mathrm{g}$ of wild-type human p53 with either no competitor (lane 2), $100 \mathrm{ng}$ of poly[d(I-C)] (lane 3), 20 or 40 pmoles of unlabeled RGC-W (lanes 4 and 5, respectively), 20 or 40 pmoles of unlabeled RGC-M (lanes 6 and 7, respectively), and 2, 4, and $6 \mu \mathrm{g}$ of human p53-specific monoclonal antibody PAb 1801 (lanes 8-10, respectively). Lane 1 contains mixture without $\mathrm{p} 53$. cleotide competitor, the percentage of labeled RGC-W oligonucleotide, bound dropped to $8 \%$ (lane 6 ) while that of labeled SV40 oligonucleotide bound dropped to $3 \%$ (lane 13). When competing with the same amount of unlabeled RGC-W oligonucleotide the amount of labeled RGC-W bound dropped to $6 \%$ (lane 8 ) and the amount of labeled SV40 oligonucleotide bound dropped to $1 \%$ (lane 15). Thus, p53 binds with similar affinities to MCK and RGC-W sequences but less well to the SV40 DNA sequence. Nonetheless, p53 binding to the SV40 oligonucleotide was clearly greater than to the nonspecific RGC-M oligonucleotide.

Binding of p53 to the RGC and SV40 oligonucleotides was also assayed by nitrocellulose filter binding (Fig. 3). With increasing ratios of p53 protein to oligonucleotide up to $\sim 2000: 1$, there was no steady increase in the percent of the nonspecific oligonucleotide bound. Using similar ratios, both the SV40 and RGC-W oligonucleotides were retained on the filter, although here again the RGC-W oligonucleotide was bound at least twofold more efficiently than was the SV40 oligonucleotide. It is not clear why the plateau of the level of RGC-W oligonucleotide bound was only $18 \%$. Possibly, we cannot monitor $100 \%$ of the DNA bound owing to the rapid on/off rate of p53, which, as we have determined by association and dissociation rate studies, is on the order of seconds (data not shown). We have calculated apparent affinities for p53 binding to the RGC-W and SV40 oligonucleotides from these data. The apparent equilibrium dissociation constant $\left(K^{\text {app }}\right)$ was $6 \times 10^{-9} \mathrm{M}$ for RGC and $12 \times 10^{-9} \mathrm{M}$ for SV40, although this may be an overestimate of the affinity, as binding to SV40 did not reach plateau levels. In support of these data, the previously determined minimum amount of $\mathrm{p} 53$ required to protect the SV40 DNA-binding region from DNase I digestion (Bargonetti et al. 1991) is twice as much as that needed to detect a clear DNase I protected region on both RGC-W (see Fig. 5, below) and MCK (Zambetti et al. 1992); and 

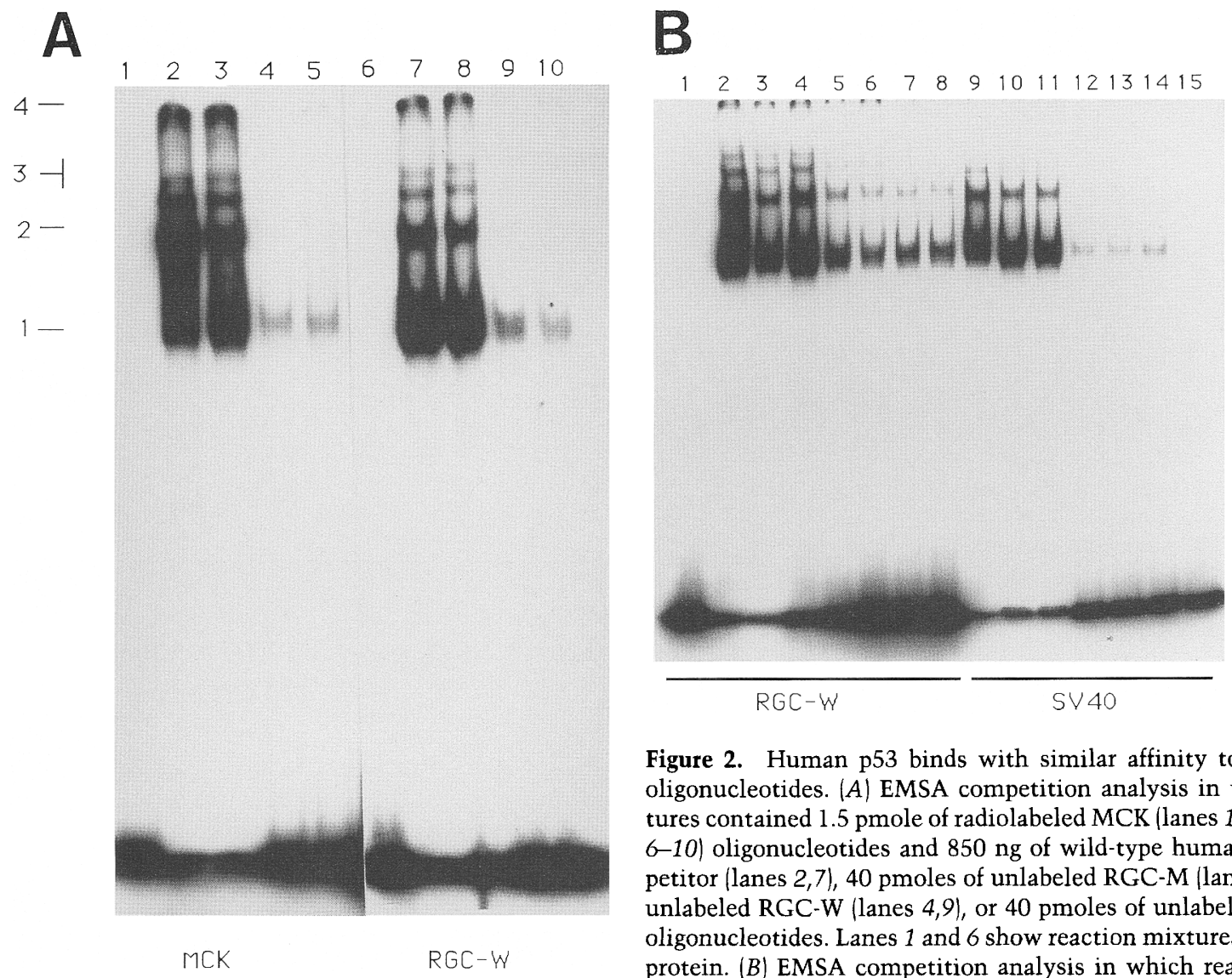

Figure 2. Human p53 binds with similar affinity to RGC-W and MCK oligonucleotides. (A) EMSA competition analysis in which reaction mixtures contained 1.5 pmole of radiolabeled MCK (lanes 1-5) or RGC-W (lanes 6-10) oligonucleotides and $850 \mathrm{ng}$ of wild-type human p53 with no competitor (lanes 2,7), 40 pmoles of unlabeled RGC-M (lanes 3,8), 40 pmoles of unlabeled RGC-W (lanes 4,9), or 40 pmoles of unlabeled MCK (lanes 5,10) oligonucleotides. Lanes 1 and 6 show reaction mixtures that contain no p53 protein. $(B)$ EMSA competition analysis in which reaction mixtures contained 1.5 pmole of radiolabeled RGC-W (lanes 1-8) or SV40 (lanes 9-15) oligonucleotides and $1 \mathrm{ng}$ of wild-type human p53 with no competitor (lanes 2,9), 20 (lanes 3,10) or 40 (lanes 4,11) pmoles of unlabeled RGC-M, 20 (lanes 5,12) or 40 (lanes 6,13) pmoles of unlabeled SV40, and 20 (lanes 7 and 14) or 40 (lanes 8,15) pmoles of unlabeled RGC-W oligonucleotides. The mixture shown in lane 1 contains no p53 protein.

the molar concentrations required for DNase I protection corresponded to the calculated $K^{\text {app }}$. There is a discrepancy between the relative binding affinities observed by EMSA and nitrocellulose filter binding. The fact that in the former case we see very little difference in binding affinity between RGC-W and SV40 in the presence of nonspecific competitor might be explained by the "caging" phenomenon described by Fried and Crothers (1981), in which protein-DNA interactions are stabilized in the gel matrix.

\section{Wild-type but not mutant $p 53$ proteins protect the RGC cellular DNA sequence}

We analyzed the ability of different $\mathrm{p} 53$ proteins to bind specifically to the RGC-binding sequence by DNase I footprinting analysis. Both wild-type murine and human p53 proteins displayed similar clear protection patterns on the labeled fragment (Fig. 4, cf. lanes 2 and 3 with 4 and 5). The region of the DNA fragment containing the RGC sequence was completely protected. In addition, a pattern of alternating regions of DNase I protection and hypercutting extended into the plasmid DNA sequence of the fragment. This rather unique extension of the pro- tection pattern was also evident with two other sequences bound by p53: SV40 (Bargonetti et al. 1991) and MCK (Zambetti et al. 1992). Tumor-derived his273 (lanes 6,7), trp248 (lanes 8,9), and his175 (lanes 10,11) mutant p53 proteins, at equivalent concentrations to those of the wild-type proteins, displayed virtually no protection of the RGC site.

\section{SV40 mutant ts $A$ T antigens conditionally inhibit p53 binding to $R G C D N A$}

We reported previously that SV40 T antigen inhibits the ability of p53 to bind specifically to the late origin-proximal region of SV40 DNA, which contains several binding sites for the transcription factor Sp1 (Bargonetti et al. 1991). These results were of potential significance when considering the consequences of the p53- $T$ antigen interaction. However, they were compromised, in our opinion, by the fact that SV40 T antigen itself binds tightly to the region directly adjacent to that which p53 binds. Thus, we could not rule out the possibility that $T$ antigen inhibits p53 DNA binding through its own specific interaction with the SV40 origin. It was therefore of great interest to examine a p53-binding site that does not 


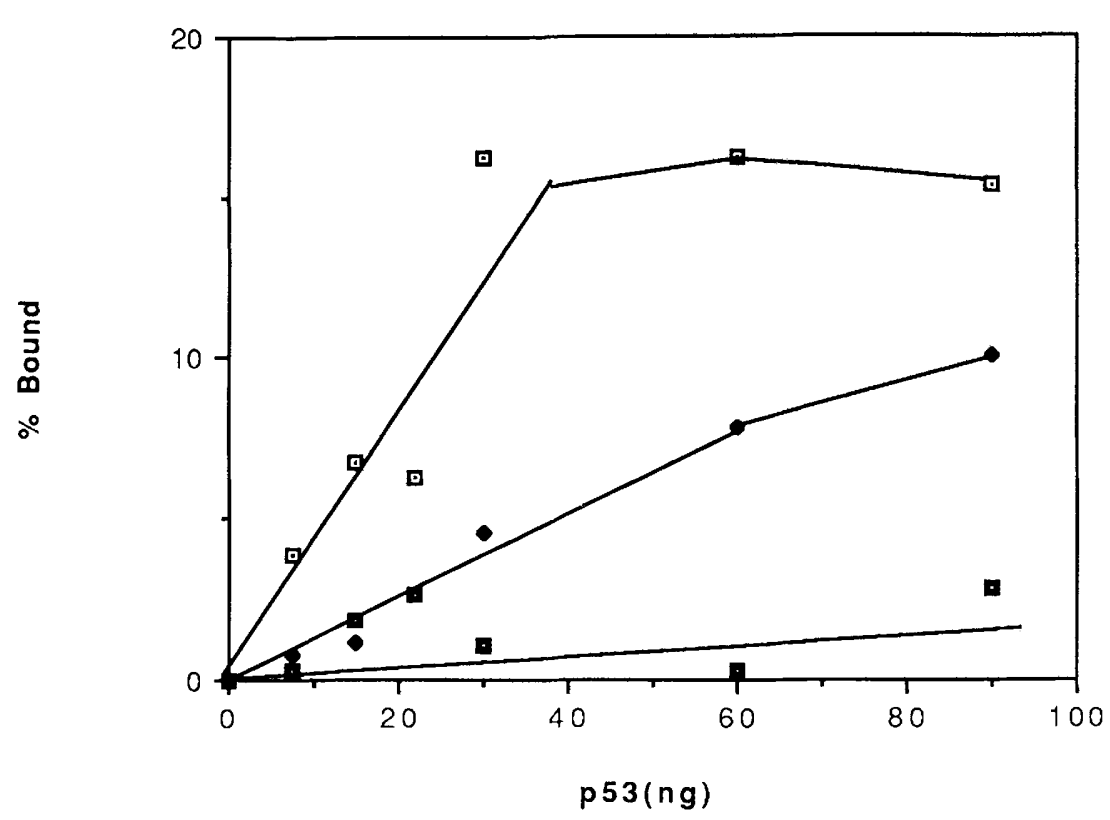

Figure 3. p53 has a higher affinity for the RGC-W than for the SV40 oligonucleotide. Binding reactions containing increasing quantities of wild-type p53 protein, RGC-W (四) SV40 ( $)$, or RGC-M (D) ${ }^{32} \mathrm{P}$-labeled oligonucleotide $\left(3 \times 10^{-11} \mathrm{M}\right)$, and $50 \mathrm{pg}$ of poly[d(I-C) were incubated for $30 \mathrm{~min}$ at $20^{\circ} \mathrm{C}$ and filtered through $0.45-\mu \mathrm{m}$ nitrocellulose filters. The filters were counted by liquid scintillation.

contain sequences with which $\mathrm{T}$ antigen also binds specifically. Examination of the MCK site revealed that it contains two closely spaced copies of the $\mathrm{T}$ antigen consensus-binding pentanucleotide $5^{\prime}$-GA/GGGC- $3^{\prime}$ and thus was not an ideal choice. We therefore decided to analyze the effects of $\mathrm{T}$ antigen on the RGC site interaction with $\mathrm{p} 53$ (Fig. 5). As predicted, SV40 $\mathrm{T}$ antigen did not bind specifically to the RGC sequence (Fig. 5A, lane 8). Nevertheless, it completely inhibited p53 site-specific binding to this site (Fig. 5A, lane 5), suggesting that the direct interaction between the SV40 T antigen and p53 is the major determinant for this inhibition. We also observed that the order of addition of $\mathrm{p} 53$ and $\mathrm{T}$ antigen did not influence this inhibition, a result that might be related to the fast on/off rate of p53 for DNA /data not shown).

Temperature-sensitive mutant SV40 $\mathrm{T}$ antigens (tsA357R-K and tsA438A-V) are oncogenic at the permissive temperature $\left(33^{\circ} \mathrm{C}\right)$ but unable to transform cells at the restrictive temperature $\left(41^{\circ} \mathrm{C}\right.$ ) (for review, see Tooze 1981). Whereas at $41^{\circ} \mathrm{C}$ wild-type SV40 $\mathrm{T}$ antigen can bind to $\mathrm{p} 53$, it has been reported that tsA438 $\mathrm{T}$ antigen is not able to bind to $\mathrm{p} 53$ at the higher temperature (Linzer et al. 1979; Montenarh et al. 1984, 1985). Baculoviruses expressing the two ts A mutant $T$ antigens were constructed, and the mutant $T$ antigens were purified from insect cells. Both of these temperature-sensitive $T$-antigen proteins were shown to mediate replication of SV40 origin containing DNA after preincubation at $33^{\circ} \mathrm{C}$ but not at $41^{\circ} \mathrm{C}$ (tsA438, Reynisdóttir et al. 1990; tsA357, Reynisdóttir and Prives 1992). To extend the relationship between the transformation potential of SV40 T antigen and the ability of $\mathrm{T}$ antigen to inhibit p53 DNA binding, tsA357 and tsA438 $\mathrm{T}$ antigens were also tested for their ability to inhibit p53 RGC binding after incubation at $33^{\circ} \mathrm{C}$ and $41^{\circ} \mathrm{C}$ (Fig. $5 \mathrm{~A}, \mathrm{~B}$ ). At the permissive temperature $\left(33^{\circ} \mathrm{C}\right)$ both tsA mutant $\mathrm{T}$ antigens pre- vented p53 DNA binding (Fig. 5A, lanes 6,7). As was the case for wild-type $T$ antigen, no specific binding to the RGC sequence was exhibited by either tsA mutant $T$ antigen alone (Fig. 5A, lanes 9,10). Strikingly, in contrast to the result seen at the permissive temperature, after preincubation at $41^{\circ} \mathrm{C}$, wild-type $T$ antigen retained the ability to inhibit p53 DNA binding (Fig. 5B, lanes 3,4), whereas neither tsA357 (Fig. 5B, lanes 5,6) nor tsA438 (Fig. 5B, lanes 7,8 ) mutant proteins significantly prevented p53 DNA-binding. These data therefore suggest that there is a direct relationship between the ability of $\mathrm{T}$ antigen to inhibit p53 DNA binding and the ability of $\mathrm{T}$ antigen to transform cells.

\section{Mutant $p 53$ proteins exhibit variability in dominant-negative effect}

Introduction of plasmids expressing high levels of mutant p53 into cells causes oncogenic changes in their growth properties. As p53 proteins are oligomeric (McCormick et al. 1981; Kraiss et al. 1988; O'Reilly and Miller 1988; Stenger et al. 1992; P.N. Friedman, X.-B. Chen, J. Bargonetti, and C. Prives, in prep.) and as heterooligomeric complexes between $\mathrm{p} 53$ proteins from different species, or between wild-type and mutant proteins from similar or different species, can form (Friedman et al. 1990; Milner et al. 1991), it is likely that introduction of mutant $\mathrm{p} 53$ proteins into cells results in the formation of heterocomplexes containing both the resident wildtype cellular p53 and the mutant p53. Because mutant p53 cannot bind site specifically to DNA it was of interest to determine whether mutant p53 proteins inhibit the DNA-binding ability of wild-type p53. Initially we tested this possibility by adding purified mutant $\mathrm{p} 53$ proteins to reactions containing a level of wild-type p53 that was able to protect the RGC sequence from DNase I digestion (Fig. 6, lanes 5-10). Under these conditions, up 


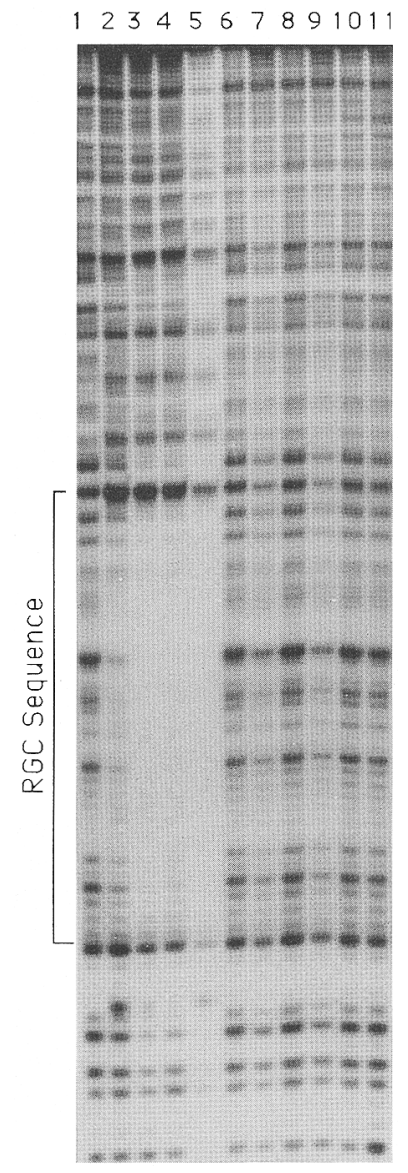

Figure 4. Wild-type but not mutant p53 proteins bind specifically to the RGC sequence. DNase I footprinting reactions were carried out as described in Materials and methods. The RGC region protected by p53 is indicated at left. Binding reaction mixtures contained no protein (lane 1) or 20 and $40 \mathrm{ng}$ of wildtype murine p53 (lanes 2 and 3, respectively), wild-type (lanes 4 and 5, respectively), his 273 mutant (lanes 6 and 7, respectively), trp248 mutant (lanes 8 and 9, respectively), or his175 mutant (lanes 10 and 11 , respectively) human p53 proteins.

to a fourfold molar excess of each of the three mutant p53 proteins did not inhibit wild-type p53 binding. The inability of mutant p53 proteins to block binding by wild-type p53 is consistent with the observation that wild-type and mutant human $\mathrm{p} 53$ proteins do not form a complex when mixed in vitro.

Insect cells coinfected with baculoviruses expressing wild-type murine p53 and either wild-type human or one of the three mutant human $\mathrm{p} 53$ s produce hetero-oligomeric complexes (Friedman et al. 1990, and unpubl.). The murine $\mathrm{p} 53$ and human 553 proteins can be discerned by their different electrophoretic mobilities and reactivity with species-specific monoclonal antibodies. We therefore tested the DNA-binding ability of p53 protein complexes immunopurified from insect cells that had been coinfected with wild-type murine p53 and either wild-type or each of three mutant human p53 recombinant baculoviruses. The purified proteins from these cells were examined by PAGE to determine the ratio of murine to human protein (Fig. 7A). Each murine p53/mutant human p53 combination contained proportionally either equal or lesser quantities of human protein as determined by silver staining (Fig. 7A, lanes 1-3). Western blot analysis with mouse-specific (PAb 248) and human-specific (PAb 1801) monoclonal antibodies (Fig. 7B) demonstrated the relative levels of the human or murine protein present.

We compared the DNA-binding ability of purified wild-type murine p53 alone with those of the wild-type murine p53/human p53 complexes described in Figure 7, $\mathrm{A}$ and $\mathrm{B}$. The various murine/mutant human p53 complexes used were "normalized" such that equivalent quantities of murine p53 were present in the DNA-binding reactions. The wild-type murine p53/wild-type human p53 complex contained relatively less murine p53 than did the other complexes (Fig. 7A,B, lanes 4) and, therefore, was not adjusted to match in quantity the purified wild-type murine p53 levels used because of the very large excess of human 553 protein that would have been present in reaction mixtures (Fig. 7A,B, lanes 5). By DNase I footprinting analysis, the purified wild-type murine/wild-type human p53 complex protected the RGC sequence to a similar extent as did purified murine p53 alone (Fig. 7C, cf. lanes 2 and 3 with 4 and 5). However, when the purified wild-type murine/mutant human p53 complexes were assayed for binding, striking results were obtained. First, the different complexes showed variation in their ability to protect the RGC sequence. Second, this variability was not proportional to the relative quantity of mutant human p53 present in the complexes as estimated from silver-stained polyacrylamide gels. For example, the complex containing the his 273 mutant p 53 contained a markedly greater amount of murine p53 than the mutant human form (Fig. 7A, lane 1) yet exhibited no competence for DNA-binding ability (Fig. 7C, lanes 6,7). Thus, the his 273 mutation is strongly dominant to wild-type p53 for site-specific DNA binding. The complex containing the his 175 mutant p53 contained approximately equal amounts of murine and human protein (Fig. 7A, lane 3) and was also unable to bind to the RGC sequence (Fig. 7C, lanes 10,11). Interestingly, the complex that contained the trp248 mutant p53 displayed nearly wild-type levels of protection of the RGC site (Fig. 7C, lanes 8,9), despite the fact that it contained approximately equal amounts of murine and human protein (Fig. 7A, lane 2). This somewhat unexpected result was confirmed repeatedly with murine/trp248 mutant human p53 complexes made at different times. Thus, mutant p53 proteins can impair the DNA-binding function of wild-type p53 by forming mixed oligomers, but their effect can range from very toxic to nearly inert. Furthermore, the fact that the least inhibitory mutant p53 is that corresponding to the Li-Fraumeni patient syndrome mutation may be related to the fact that such individuals can bear germ-line mutations at this p53 residue.

To further characterize the DNA-binding properties of the complex containing the trp248 mutant p53, EMSA 
Figure 5. SV40 tsA $\mathrm{T}$ antigens conditionally inhibit p53 binding to the RGC sequence. DNase I footprinting reactions were carried out as described in Fig. 4. $|A|$ Analysis of binding to a ${ }^{32} \mathrm{P}$-labeled RGC-containing fragment at $33^{\circ} \mathrm{C}$ with no protein (lane 1) or 10 (lane 2), 20 (lane 3), 30 (lane 4) ng of wild-type human p53 or 30 $\mathrm{ng}$ of wild-type p53 with $80 \mathrm{ng}$ of either wild-type T antigen (lane 5), tsA357 (lane 6), or tsA438 (lane 7) mutant $\mathrm{T}$ antigens. Reaction mixtures containing no p53 but with $80 \mathrm{ng}$ of either wild-type $\mathrm{T}$ antigen (lane 8 ), tsA357 (lane 9), or tsA438 (lane 10) mutant T antigens are also shown. Wild-type and mutant $\mathrm{T}$ antigens were preincubated at $33^{\circ} \mathrm{C}$ for $15 \mathrm{~min}$ before addition to reaction mixtures. (B) Analysis of binding to ${ }^{32} \mathrm{P}$-labeled RGC-containing fragment at $37^{\circ} \mathrm{C}$ with no protein (lane 1), $30 \mathrm{ng}$ of wild-type p53 (lane 2), or $30 \mathrm{ng}$ of wild-type p53 with 40 or $80 \mathrm{ng}$ of either wild-type $\mathrm{T}$ antigen (lanes 3 and 4 , respectively), mutant $T$ antigen ts $A 357$ (lanes 5 and 6, respectively), or tsA438 (lanes 7 and 8, respectively). Binding mixtures with no $\mathrm{p} 53$, but containing $80 \mathrm{ng}$ of either wild-type T antigen (lane 9), tsA357 (lane 10 ), or tsA438 (lane 11) mutant $\mathrm{T}$ antigens, are also shown. Wild-type and mutant $T$ antigens were preheated at $41^{\circ} \mathrm{C}$ for $15 \mathrm{~min}$ before the addition to reaction mixtures.
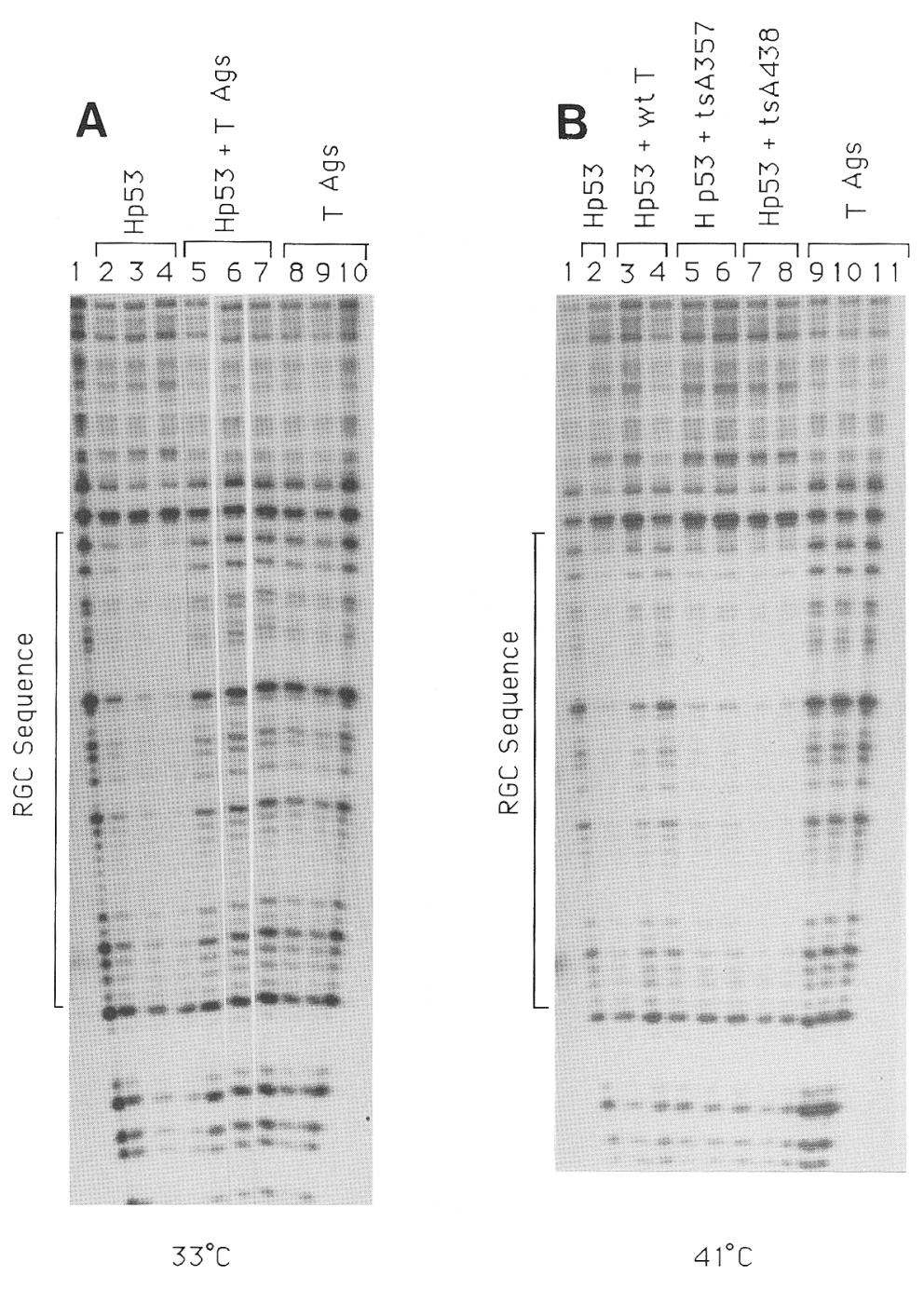

was performed (Fig. 8). Confirming the results of the DNase I footprint analyses, while the trp 248 mutant p53 was completely inactive in this assay, when complexed to murine p53, it formed DNA-protein complexes in a similar fashion to either the wild-type mouse or human p53 proteins alone. While coimmunoprecipitation analysis with murine- and human-specific antibodies indicated that the $\mathrm{p} 53$ proteins in the wild-type/mutant $\mathrm{p} 53$ complex were bound to one another (data not shown), it was of interest to determine whether the trp248 mutant human protein could be detected within the DNA-p53 protein complexes containing murine $\mathrm{p} 53$. We therefore asked whether the human-specific antibody PAb 1801 was able to interact with the murine/mutant human p53 DNA complex. As shown in Figure 8, not only was there a supershift observed with human p53 alone but also with the complex containing the trp248 mutant human/ wild-type murine p53 proteins. As expected, PAb 1801 did not affect the mobility of the DNA-protein complexes containing wild-type murine p53 alone. These data therefore show that while the trp248 mutant human p53 alone is not able to interact with DNA, it can participate directly in forming a DNA-protein complex when associated with a wild-type p53.

\section{Discussion}

Our data indicate that p53 binds with relatively high affinity and specificity to three different known DNA sequences. In all cases, EMSA assays displayed several discrete protein-DNA complexes containing p53. Analysis of purified p53 protein in the absence of DNA by nondenaturing PAGE has revealed that it exists as distinct oligomers that represent tetramers and multiples thereof (Stenger et al. 1992; P.N. Friedman, X.-B. Chen, J. Bargonetti, and C. Prives, in prep.). Our data with EMSA indicates that these various oligomers of $\mathrm{p} 53$ are all capable of binding to DNA. Evidence that the unit multimer of p53 is a tetramer is supported by experiments utilizing cross-linking, zonal velocity, density gradient centrifugation, and gel filtration analyses (Stenger et al. 1992; P.N. Friedman, X.-B. Chen, J. Bargonetti, and C. Prives, in prep.). By analysis of the Stokes radius and sedimentation coefficient of $\mathrm{p} 53$ we have calculated a 


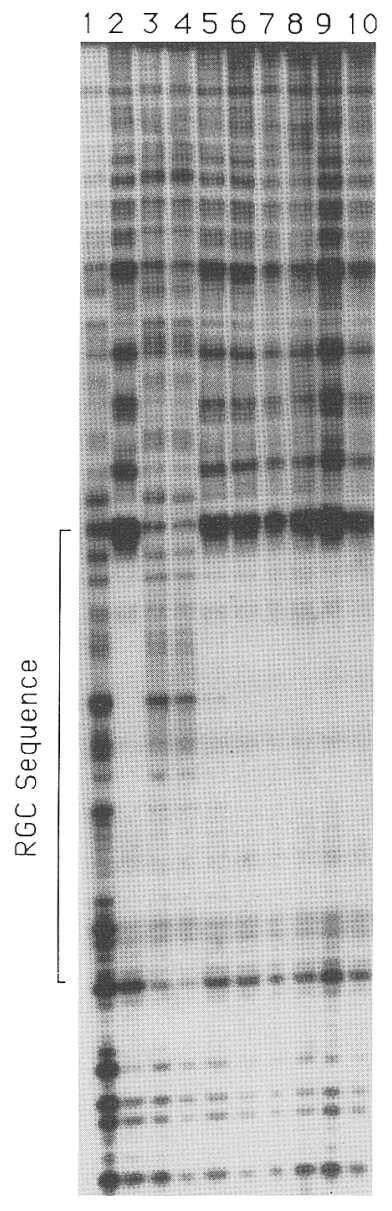

Figure 6. Added mutant $\mathrm{p} 53$ proteins do not inhibit DNA binding by wild-type p53. DNase I protection analysis of ${ }^{32} \mathrm{P}$-labeled RGC sequence-containing fragment as in Fig. 4 bound to no protein (lane 1), $70 \mathrm{ng}$ of wild-type murine p53 (lane 2), or $70 \mathrm{ng}$ of murine p53 plus two levels ( 140 and $280 \mathrm{ng}$ ) of added SV40 T antigen (lanes 3 and 4, respectively), or his273 (lanes 5 and 6, respectively), trp248 (lanes 7 and 8 , respectively), or his175 (lanes 9 and 10, respectively) immunopurified human mutant p53 proteins.

frictional coefficient of 1.75 , indicating that the p53 tetramer has a long, extended shape (P.N. Friedman, X.-B. Chen, J. Bargonetti, and C. Prives, in prep.). Comparing p53 DNase I footprints on RGC DNA in this study with its protection of sites on SV40 (Bargonetti et al. 1991) and MCK (Zambetti et al. 1992) DNA fragments, we have noted a consistently striking pattern of protection in which sequences extending from the actual specific site are alternately protected and hypersensitive to DNase I cutting. These auxiliary patterns may be the result of the extended p53 protein multimers wrapping around or spreading out over the DNA.

The ability of p53 to bind specifically to SV40, MCK, and RGC suggests that the sequences with which p53 interacts are diverse. However, El-Deiry et al. (1992) recently reported the identification of a number of additional genomic sites to which $\mathrm{p} 53$ binds which each con- tain a dimer of a double-stranded motif that loosely fits the sequence 5'-Pu Pu Pu C (A/T) (T/A) G Py Py Py-3'. The three sites used in our experiments herein also contain versions of this consensus sequence. That p53 is an extended tetramer fits well with the nature of the duplicated cognate symmetrical p53-binding site.

Recently, p53 was shown to activate transcription of plasmids containing reporter templates bearing p53binding sites in vivo (Funk et al. 1992; Kern et al. 1992; Scharer and Iggo 1992; Zambetti et al. 1992) and in vitro (Farmer et al. 1992). The sequences of both the MCK and RGC oligonucleotides used in this study are sufficient to confer p53-mediated activated expression from such constructs. Although the significance of either of these sites to the role of p53 in cell regulation is not obvious, such experiments bring into focus the likelihood that p53 is a transcription factor that exerts its influence through specific interactions with DNA. The potential importance of this function is highlighted by the fact that tumorderived p53 mutants are all defective in DNA binding. Loss of DNA binding could therefore be a means of preventing the activation of specific genes by p53.

Our experiments have furthered the connection between inhibition of p53 DNA binding and loss of normal p53 function. SV40 T antigen was shown to completely block the binding of p53 to the RGC site. The ability of SV40 $\mathrm{T}$ antigen to affect the growth of certain cell types is tightly correlated with its ability to bind p53 (Lin and Simmons 1991; Zhu et al. 1991, 1992). Our results, which demonstrate that two temperature-sensitive $T$ antigens inhibit p53 DNA binding at the permissive, but not at the restrictive, temperature, provide evidence that the transforming potential of $T$ antigen is the result of its interaction with and subsequent inactivation of $\mathrm{p} 53$ function. This would be an explanation for why, at the nonpermissive temperature, these mutant proteins cannot transform cells. The products of other DNA tumor viruses also alter the function of wild-type p53. The product of the E6 gene of oncogenic forms of human papillomaviruses targets p53 for rapid degradation through the ubiquitin-mediated proteolytic pathway (Scheffner et al. 1990). In addition, the adenovirus E1B $58-\mathrm{kD}$ protein product that binds to $\mathrm{p} 53$ was shown recently to inhibit the function of the transcriptional activation domain of p53-GAL4 hybrid proteins (Yew and Berk 1992). The fact that the SV40 and adenovirus products block the DNA-binding and transcriptional activation properties of $\mathrm{p} 53$, respectively, supports the suggestion that DNA-binding-dependent transcriptional activation may be key in p53 control of cell growth and DNA replication. We have found that $\mathrm{p} 53$ activation of transcription in vitro from templates containing the RGC sequence upstream of basal promoter elements is inhibited by the addition of $\mathrm{T}$ antigen (Farmer et al. 1992). This result is most likely due to the fact that $T$ antigen prevents the binding of p53 to the RGC site (as shown in this study).

Complexes containing both mutant and wild-type p53 displayed interesting variations in their ability to bind to DNA. While those containing wild-type and either 

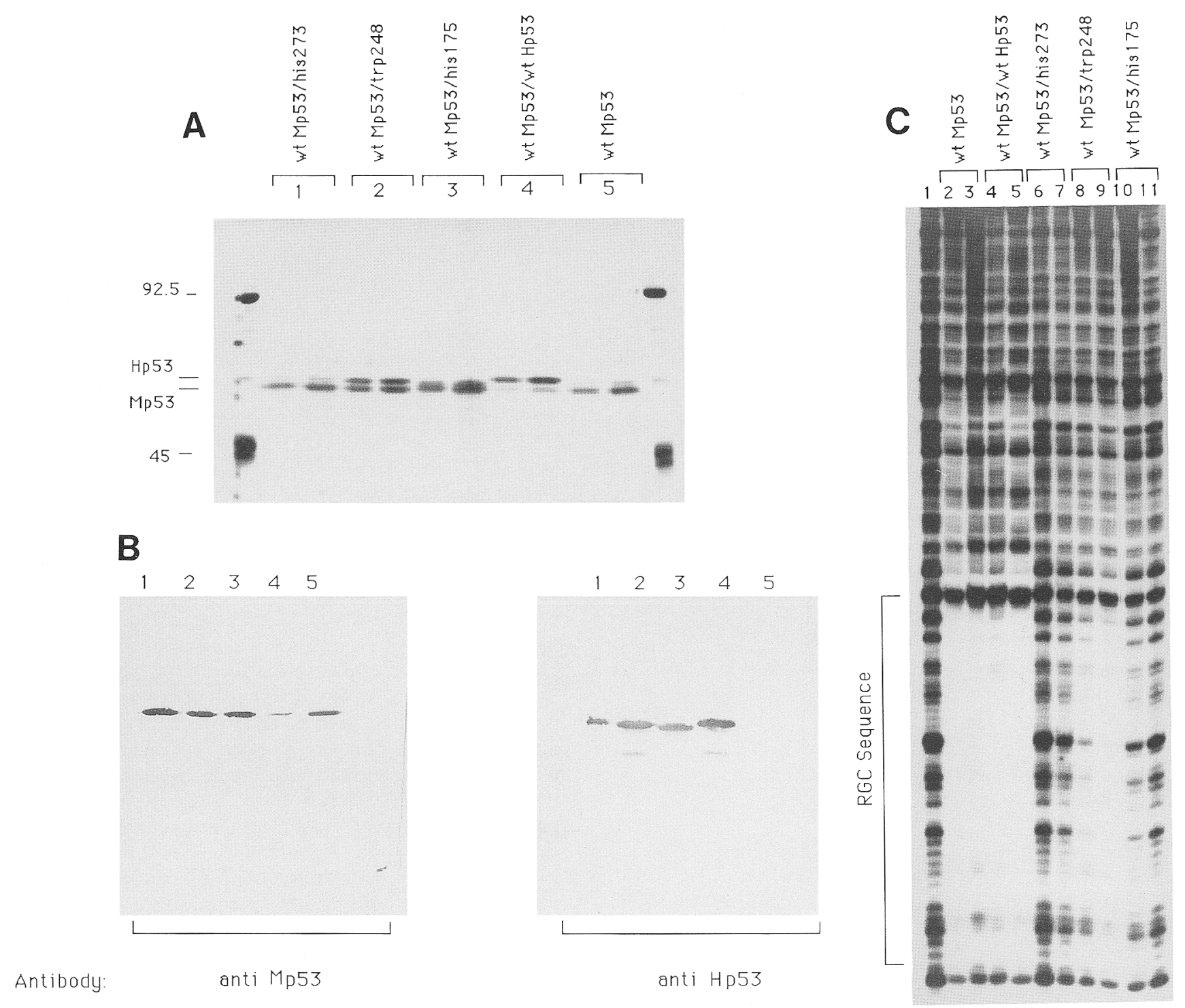

Figure 7. Cotranslated complexes containing wild-type murine p53 with different mutant human p53 proteins exhibit variability in their DNA-binding ability. (A) Silver-stained SDS-polyacrylamide gel analysis of 5 and $10 \mu \mathrm{l}$ of complexes as indicated (lanes 1-4) or murine p53 alone (lane 5). Positions of human and murine p53 proteins and molecular mass markers (in $\mathrm{kD}$ ) are shown at left. (Hp53) Human $\mathrm{p} 53,(\mathrm{Mp} 53)$ murine $\mathrm{p} 53$. (B) Western blot analysis of proteins corresponding to lanes containing the higher level of protein shown in $A$ was carried out with murine-specific antibody PAb 248 (left) or with human specific antibody PAb 1801 (right). (C) DNase I protection analysis of the ${ }^{32}$ P-labeled RGC-containing fragment as in Fig. 4 bound to no protein (lane 1 ), two levels (30 and 60 ng) of wild-type murine p53 (lanes 2,3), or complexes containing wild-type murine and either wild-type human p53 proteins (lanes 4,5) or mutant human p53 proteins as indicated, adjusted such that the amounts of protein added contained 30 and $60 \mathrm{ng}$ of murine p53.

his175 or his273 mutant proteins failed to bind to DNA, a complex containing the trp248 mutant p53 displayed competence for such binding. Whereas mutations occurring within human tumors have apparently lost wildtype function, introduction of plasmids expressing $\mathrm{mu}$ tant p53 into cells can function as active in immortalization and oncogene cooperation assays. In particular, the oncogenically derived his 175 and his 273 mutant p53 proteins both cooperate with ras to transform primary rat embryo fibroblasts (Hinds et al. 1990). Cotranslation of activated mutant p53 with wild-type p53 causes the wild-type p53 to assume a mutant conformation, as judged by reactivity with conformation-specific antibodies (Milner and Medcalf 1991). Thus, these mutant p53 proteins, when introduced into cells by various protocols, may assemble with the resident wild-type p 53 protein and poison its activity. The data we obtained with the his175 and his273 mutant p53 proteins are also consistent with the fact that these same complexes fail to activate transcription in vitro (Farmer et al. 1992). The Li-Fraumeni mutant trp248 is representative of a p53 mutation that is inherited through the germ line and 


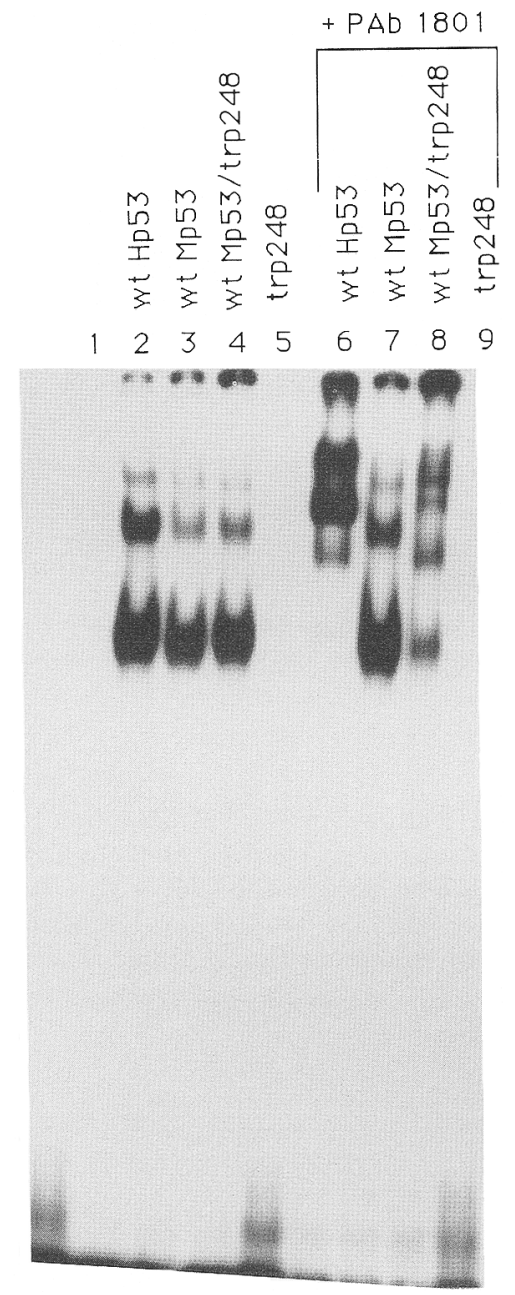

Figure 8. The trp248 mutant human $\mathrm{p} 53$ protein binds directly to DNA when complexed with wild-type murine p53. EMSA analysis of reaction mixtures containing ${ }^{32}$ P-labeled RGC (1.5 pmole) and poly $[\mathrm{d}(\mathrm{I}-\mathrm{C})](100 \mathrm{ng})$ with either no protein (lane 1), $200 \mathrm{ng}$ of wild-type human p53 (lanes 2,6), $200 \mathrm{ng}$ of murine p53 (lanes 3,7), $400 \mathrm{ng}$ of complex containing wild-type murine and trp248 mutant human p53 protein (lanes 4,8), or $200 \mathrm{ng}$ of trp248 mutant human p53 proteins (lanes 5,9). Mixtures shown in lanes $6-9$ contained $6 \mu \mathrm{g}$ of human-specific p 53 monoclonal antibody (PAb 1801).

causes individuals to have a $50 \%$ probability of developing malignant carcinoma by the age of 30 (Malkin et al. 1990; Srivastava et al. 1990). The trp248 mutant allele can be inherited with no detrimental effect to development. Moreover, Milner and Medcalf (1991) found that unlike other p53 mutants, coexpression of trp248 mutant p53 with wild-type p53 does not drive the wild-type protein into the mutant conformation. Thus, the trp248 mutation may not function in a dominant-negative manner. However, it must be noted that constructs expressing several mutant p53 proteins, including the trp 248 mutant, were shown to inhibit wild-type p53-mediated activation of transcription from RGC-binding site-containing plasmids in cell transfection assays (Kern et al.
1992). Nevertheless, in that study, the ratio of mutant to wild-type p53 expressed in transfected cells was not reported, and complexes containing a high ratio of trp248 mutant to wild-type p53 might be more defective. Alternately, wild-type/trp248 mutant p53 complexes may be capable of binding DNA but not activating transcription. We are currently testing these and other possibilities.

In addition to activating transcription, wild-type p53 can repress transcription of many genes. A role for $\mathrm{p} 53$ in regulation of DNA replication based on both in vitro (Gannon and Lane 1987; Sturzbecher et al. 1988; Wang et al. 1989) and in vivo (Braithwaite et al. 1987; Kastan et al. 1991; Wilcox and Lane 1991) studies has also been postulated. It can be speculated that these functions are dependent on site-specific DNA binding by $\mathrm{p} 53$. The mounting evidence that DNA binding is central to the normal function of $\mathrm{p} 53$ should provide the impetus to identify genes with activities that are controlled by the DNA-binding ability of p53 and also to identify factors that regulate such binding. Furthermore, whether or not mutated p53 proteins contribute to tumor progression through regulation of wild-type p53 is a question that deserves careful attention.

\section{Materials and methods}

\section{Purification of p53 and SV40 T antigen proteins}

Recombinant baculoviruses expressing wild-type human or his 273 and his175 mutant p53 proteins were described previously (Bargonetti et al. 1991 and references therein). Similarly, the construction of recombinant baculoviruses vEV55SVT, expressing wild-type SV40 T antigen (O'Reilly and Miller 1988), or vEV55SVtsA30 and vEV55SVtsA58, expressing tsA 357R-K and tsA 438A-V mutant $T$ antigens, respectively (Reynisdótter et al. 1990; Reynisdótter and Prives 1992) has been described. Construction of recombinant baculovirus expressing trp 248 mutant p53 was by a protocol similar to that used to generate the other human p53 viruses (Friedman et al. 1990). The baculovirus encoding wild-type murine p53 was a generous gift from $M$. Oren (Weizmann Institute, Israel). Sf 21 insect cells that served as host cells for all baculoviruses used in this study were grown at $27^{\circ} \mathrm{C}$ in TC-100 medium (GIBCO) containing 10\% heat-inactivated fetal calf serum and $0.25 \%$ tryptose broth.

Sf 21 cells $\left(2.5 \times 10^{7} / 150\right.$-mm dish) were infected with recombinant viruses and harvested $48 \mathrm{hr}$ after infection. Extracts of infected cells were prepared, and p53 and $T$ antigen proteins were purified from cell lysates by immunoaffinity procedures essentially as described (Wang et al. 1989). Protein A-Sepharose columns to which the p53-specific monoclonal antibody PAb 421 (Harlow et al. 1981) was cross-linked were used to purify p53 proteins. T-antigen proteins were purified using similar columns containing $T$ antigen-specific monoclonal antibody PAb 419 (Harlow et al. 1981). To prepare complexes containing murine and human $\mathrm{p} 53$ proteins, insect cells were coinfected with recombinant baculoviruses expressing wild-type murine p53 and each of the different human p53 proteins at comparable multiplicities of infection, and proteins were then purified using PAb 421 columns as described above.

\section{DNA-binding assays}

EMSA The synthetic oligonucleotides used in this study were either obtained from Operon or were generous gifts from $M$. 
Sherman (Pharmagenics) and were constructed with XhoI ends for end-labeling by the DNA polymerase I large fragment and $\left[{ }^{32} \mathrm{P}\right] \mathrm{dNTPs}$. The RGC $\mathrm{p} 53$-binding sequence was identified by immunoprecipitation assays and methylation interference protocols (Kern et al. 1991a). This oligonucleotide (RGC-W) has the sequence 5'-TCGAGTTGCCTGGACTTGCCTGGCCTTGCCTTTTC- $3^{\prime}$. The sequence of the mutant RGC oligonucleotide (RGC-M); 5'-TCGAGTTTAATGGACTTTAATGGCCTTTAATTTTC-3' was also derived from Kern et al. (1991a), who showed that changing each TGCCT repeat of the RGC-W oligonucleotide to TTAAT led to loss of specific binding by human p53. The MCK oligonucleotide sequence to which p53 binds (5' - TCGAGTGGCAAGCCTATACATGGCCGGGGCCTGCCTCTCTCTGCCTCTGACCT-3') was demonstrated by DNase I protection analysis (Zambetti et al. 1992). The SV40 p53-binding sequence oligonucleotide (SV40), which was also determined by DNase I protection analysis (Bargonetti et al. 1991), has the sequence $5^{\prime}$-TCGAGCTAACTCCGCCCAGTTCCCCATTCTCCGCCCCATGGC-3'.

Reaction mixtures $(50 \mu)$ for EMSA experiments contained $40 \mathrm{~mm}$ creatine phosphate, $4 \mathrm{mM}$ ATP, $7 \mathrm{mM} \mathrm{MgCl}_{2}, 0.5 \mathrm{~mm}$ DTT, $0.2 \mathrm{mg} / \mathrm{ml}$ of bovine serum albumin, and an oligonucleotide concentration of $3 \times 10^{-7} \mathrm{M}$. One microgram of wild-type human p53 was added to each reaction mixture, which was then incubated at room temperature for $30 \mathrm{~min}$, after which unlabeled competitors, either poly[d(I-C)] or oligonucleotide, were added as indicated, and the binding reactions were allowed to continue for an additional $15 \mathrm{~min}$. Purified PAb 1801 was added, as indicated, directly into the reaction mixtures and incubated for $30 \mathrm{~min}$. Protein-DNA complexes were resolved on $4 \%$ acrylamide gels.

Nitrocellulose filter binding Binding experiments were performed under essentially the same conditions as the EMSA; however, oligonucleotide concentrations of $3 \times 10^{-11} \mathrm{M}$ were used, and all mixtures contained $50 \mathrm{pg}$ of poly[d $[\mathrm{I}-\mathrm{C})]$. Wild-type human $\mathrm{p} 53$ was added as indicated. Mixtures were incubated for $30 \mathrm{~min}$ at room temperature and then filtered through $0.45-\mu \mathrm{m}$ nitrocellulose filters presoaked in wash buffer ( $25 \mathrm{mM}$ HEPES). The filters were washed twice with the same buffer and counted by liquid scintillation.

DNase I protection assays A labeled fragment containing the RGC sequence was prepared by digesting a plasmid (subclone $10 \mathrm{~d}$ of $772 \mathrm{C}_{\mathrm{BE}}$ ) (Kern et al. 1991a) with BamHI and labeling with the large fragment of DNA polymerase I and $\left[{ }^{32} \mathrm{P}\right] \mathrm{dNTPs}$. The mixture was then digested with $P_{v u I}$, and the 250-bp end-labeled fragment was gel purified. Reaction mixtures $(50 \mu l)$ containing $40 \mathrm{mM}$ creatine phosphate (di-Tris salt; $\mathrm{pH} 7.71,4 \mathrm{~mm}$ ATP, $7 \mathrm{~mm} \mathrm{MgCl}_{2} 0.2 \mathrm{mg} / \mathrm{ml}$ of bovine serum albumin, $0.5 \mathrm{~mm}$ DTT, $10 \mathrm{ng}$ of pBR322, and 10-12 fmoles of ${ }^{32} \mathrm{P}$-labeled DNA fragment were preincubated for $5 \mathrm{~min}$ at $37^{\circ} \mathrm{C}$. Proteins were added, and the reaction was allowed to proceed for $15 \mathrm{~min}$. The amount of DNase I required to produce an even pattern of partial cleavage products was pretested empirically; in general, $4-10 \mu \mathrm{l}$ of a freshly diluted $0.5-\mu \mathrm{g} / \mathrm{ml}$ solution in 20 $\mathrm{mM} \mathrm{CaCl}_{2}$ was used. Following digestion, $50 \mu$ l of DNase I stop solution $(2 \mathrm{M}$ ammonium acetate, $100 \mathrm{mM}$ EDTA, $0.2 \%$ SDS, $100 \mu \mathrm{g} / \mathrm{ml}$ of sheared salmon sperm DNA) was added, and the DNA was extracted with phenol and ethanol precipitated. The DNA was then analyzed by electrophoresis through $8 \%$ denaturing polyacrylamide gels.

\section{SDS-PAGE and Western blot analysis}

Duplicated samples of immunopurified p 53 proteins were subjected to $10 \%$ SDS-PAGE and either silver stained or electro- transferred to nitrocellulose. In the latter case, half of the filter was probed with the human-specific p53 monoclonal antibody PAb 1801 (Banks et al. 1986), and the other half was probed with the murine-specific p53 monoclonal antibody PAb 248 (Yewdell et al. 1986).

\section{Acknowledgments}

We thank Ella Fruelich for expert technical assistance. B. Vogelstein and A.J. Levine and members of their respective laboratories are thanked for providing useful reagents and information before publication. This work was supported by National Institutes of Health grant CA33620. J.B. was supported by a Damon Runyon-Walter Winchell Cancer Research Fund fellowship (DRG-1133).

The publication costs of this article were defrayed in part by payment of page charges. This article must therefore be hereby marked "advertisement" in accordance with 18 USC section 1734 solely to indicate this fact.

\section{References}

Addison, C., J.R. Jenkins, and H.W. Sturzbecher. 1990. The p53 nuclear localisation signal is structurally linked to a p34cdc2 kinase motif. Oncogene 5: 423-426.

Banks, L., G. Matlashewski, and L. Crawford. 1986. Isolation of human-p53-specific monoclonal antibodies and their use in the studies of human p53 expression. Eur. I. Biochem. 159: 529-534.

Bargonetti, J., P.N. Friedman, S.E. Kern, B. Vogelstein, and C. Prives. 1991. Wild-type but not mutant p53 immunopurified proteins bind to sequences adjacent to the SV40 origin of replication. Cell 65: 1083-1091.

Braithwaite, A.W., H. Sturzbecher, C. Addison, C. Palmer, K. Rudge, and J.R. Jenkins. 1987. Mouse p53 inhibits SV40 origin-dependent DNA replication. Nature 329: 458-460.

Chin, K., U. Kazumitsu, I. Pastan, and M.M. Gottesman. 1992. Modulation of the promoter of the human MDRl gene by ras and p53. Science 255: 459-462.

Chow, V., Y. Ben-David, A. Bernstein, S. Benchimol, and M. Mowat. 1987. Multistage Friend erythrolukemia: Independent origin of tumor clones with normal or rearranged p53 cellular oncogenes. J. Virol. 61: 2777-2781.

Donehower, L.A., M. Harvey, B.L. Slagle, M.J. McArthur, C.A. Montgomery Jr., J.S. Butel, and A. Bradley. 1992. Mice deficient for p53 are developmentally normal but susceptible to spontaneous tumours. Nature 356: 215-221.

El-Deiry, W.S., S.E. Kern, J.A. Pietenpol, K.W. Kinzler, and B. Vogelstein. 1992. Definition of a consensus binding site for p53. Nature Genetics 1: 45-49.

Farmer, G., J. Bargonetti, H. Zhu, P. Friedman, R. Prywes, and C. Prives. 1992. Wild-type p53 activates transcription in vitro. Nature 358: 83-86.

Fields, S. and S.K. Jang. 1990. Presence of a potent transcription activating sequence in the p53 protein. Science 249: 10461048.

Fried, M. and D.M. Crothers. 1981. Equilibria and kinetics of lac repressor-operator interactions by polyacrylamide gel electrophoresis. Nucleic Acids Res. 9: 6505-6525.

Friedman, P.N., S.E. Kern, B. Vogelstein, and C. Prives. 1990. Wild-type, but not mutant, human p53 proteins inhibit the replication activities of simian virus 40 large tumor antigen. Proc. Natl. Acad. Sci. 87: 9275-9279.

Funk, W.D., D.T. Pak, R.H. Karas, W.E. Wright, and J.W. Shay. 1992. A transcriptionally active DNA-binding site for hu- 
man p53 protein complexes. Mol. Cell. Biol. 12: 2866-2871.

Gannon, J.V. and D.P. Lane. 1987. p53 and DNA polymerase alpha compete for binding to SV40 $\mathrm{T}$ antigen. Nature 329: 456-458.

Ginsberg, D., F. Mechta, M. Yaniv, and M. Oren. 1991. Wildtype p53 can down-modulate the activity of various promoters. Proc. Natl. Acad. Sci. 88: 9979-9983.

Halevy, O., D. Michalovitz, and M. Oren. 1990. Different tumor-derived p53 mutants exhibit distinct biological activities. Science 250: 113-116.

Harlow, E., L.V. Crawford, D.C. Pim, and N.M. Williamson. 1981. Monoclonal antibodies specific for simian virus 40 tumor antigens. J. Virol. 39: 861-869.

Hicks, G.G., S.E. Egan, A.H. Greenberg, and M. Mowat. 1991. Mutant p53 tumor suppressor alleles release ras-induced cell cycle growth arrest. Mol. Cell. Biol. 11: 1344-1352.

Hinds, P., C. Finlay, and A.J. Levine. 1989. Mutation is required to activate the p53 gene for cooperation with the ras oncogene and transformation. I. Virol. 63: 739-746.

Hinds, P.W., C. Finlay, R.S. Quartin, S.J. Baker, E.R. Fearon, B. Vogelstein, and A.J. Levine. 1990. Mutant p53 DNA clones from human colon carcinomas cooperate with ras in transforming primary rat cells: A comparison of the "hot spot" mutant phenotypes. Cell Growth \&) Differ. 1: 571-580.

Hollstein, M., D. Sidrowsky, B. Vogelstein, and C.C. Harris. 1991. p53 mutations in human cancer. Science 253: 49-53.

Kastan, M.B., O. Onyekwere, D. Sidransky, B. Vogelstein, and R. Craig. 1991. Participation of $\mathrm{p} 53$ protein in the cellular response to DNA damage. Cancer Res. 51: 6304-6311.

Kern, S.E., K.W. Kinzler, A. Bruskin, D. Jarosz, P.N. Friedman, C. Prives, and B. Vogelstein. 1991a. Identification of p53 as a sequence-specific DNA-binding protein. Science 252: 17081711.

Kern, S.E., K.W. Kinzler, S.J. Baker, J.M. Nigro, V. Rotter, A.J. Levine, P. Friedman, C. Prives, and B. Vogelstein. 1991b. Mutant p53 proteins bind DNA abnormally in vitro. Oncogene 6: 131-136.

Kern, S.E., J.A. Pietenpol, S. Thiagalingam, A. Seymour, K.W. Kinzler, and B. Vogelstein. 1992. Oncogenic forms of p53 inhibit p53-regulated gene expression. Science 256: 827830.

Kraiss, S., A. Quaiser, M. Oren, and M. Montenarh. 1988. oligomerization of oncoprotein p53. I. Virol. 62: 4737-4744.

Lane, D.P. and S. Benchimol. 1990. p53: Oncogene or anti-oncogene? Genes \& Dev. 4: 1-8.

Levine, A.J. and J. Momand. 1990. Tumor suppressor genes: The p53 and retinoblastoma gene products sensitivity genes and gene products. Biochim. Biophys. Acta 1032: 119-136.

Levine, A.J., J. Momand, and C.A. Finlay. 1991. The p53 tumour suppressor gene. Nature 351: 453-456.

Lin, J. and D. Simmons. 1991. The ability of large T antigen to complex with p53 is necessary for the increased life span and partial transformation of human cells by simian virus 40 . $J$. Virol. 65: 6447-6453.

Linzer, D.I.H., W. Maltzman, and A.J. Levine. 1979. The SV40 A gene product is required for the production of a 54,000 MW cellular tumor antigen. Virology 98: 308-318.

Malkin, D., F.P. Li, L.C. Strong, J.F. Fraumeni Jr., C.S. Nelson, D.H. Kim, J. Kassel, M.A. Gryka, F.Z. Bischoff, M.A. Tainsky, B. Vogelstein, and S. Friend. 1990. Germ line p53 mutations in a familial syndrome of breast cancer, sarcomas, and other neoplasms. Science 250: 1233-1238.

McCormick, F., R. Clark, E. Harlow, and R. Tjian. 1981. SV40 T antigen binds specifically to a cellular $53 \mathrm{~K}$ protein in vitro. Nature 292: 63-65.

Mercer, E.W., M.T. Shields, D. Lin, E. Appela, and S.J. Ullrich.
1991. Growth suppression induced by wild-type p53 protein is accompanied by selective down-regulation of proliferating-cell nuclear antigen expression. Proc. Natl. Acad. Sci. 88: 1958-1962.

Milner, J. and E. Medcalf. 1991. Cotranslation of activated mutant $\mathrm{p} 53$ with wild-type drives the wild type p53 protein into the mutant conformation. Cell 65: 765-774.

Milner, J., E.A. Medcalf, and A.C. Cook. 1991. Tumor suppressor p53: Analysis of wild-type and mutant p53 complexes. Mol. Cell. Biol. 11: 12-19.

Montenarh, M., M. Kohler, and R. Henning. 1984. oligomerization of simian virus 40 large $\mathrm{T}$ antigen is not necessarily repressed by temperature-sensitive A gene lesions. I. Virol. 49: 658-664.

Montenarh, M., M. Kohler, G. Aggeler, and R. Henning. 1985. Structural prerequisites of simian virus 40 large $T$ antigen for the maintenance of cell transformation. EMBO J. 4: 29412947.

Mowat, M., A. Cheng, N. Kimura, A. Bernstein, and S. Benchimol. 1985. Rearrangements of the cellular p53 gene in erythroleukaemic cells transformed by Friend virus. Nature 314: 633-636.

Munroe, D.G., B. Rovinski, A. Berstein, and S. Benchimol. 1987. Loss of a highly conserved domain on p53 as a result of gene deletion during Friend virus-induced erythroleukemia. Oncogene 2: 621-624.

Nigro, J.M., S.J. Baker, C. Presinger, J.M. Jessup, R. Hostetter, K. Cleary, S.H. Bigner, N. Davidson, S. Baylin, P. Devilee, T. Glover, F.S. Collins, A. Weston, R. Modali, C.C. Harris, and B. Vogelstein. 1989. Mutations in the p53 gene occur in diverse human tumour types. Nature 342: 705-708.

O'Reilly, D.R. and L.K. Miller. 1988. Expression and complex formation of simian virus 40 large $\mathrm{T}$ antigen and mouse p53 in insect cells. J. Virol. 62: 3109-3119.

O’Rourke, R.W., C.W. Miller, G.J. Kato, K.J. Simon, D.L. Chen, C.V. Dang, and H.P. Koeffler. 1990. A potential transcriptional activation element in the $\mathrm{p} 53$ protein. Oncogene 5: 1829-1832.

Raycroft, L., H. Wu, and G. Lozano. 1990. Transcriptional activation by wild-type but not transforming mutants of the p53 anti-oncogene. Science 249: 1049-1051.

Reynisdóttir, I. and C. Prives. 1992. Two conditional tsA mutant SV40 T antigens display marked differences in thermal inactivation. J. Virol. (in press).

Reynisdóttir, I., D.R. O'Reilly, L.K. Miller, and C. Prives. 1990. Thermally inactivated simian virus 40 tsA58 mutant $\mathrm{T}$ antigen cannot initiate viral DNA replication in vitro. J. Virol. 64: 6234-6245.

Santhanam, U., R. Anuradha, and S. Pravinkumar. 1991. Repression of the interleukin 6 gene promoter by p53 and the retinoblastoma susceptibility gene product. Proc. Natl. Acad. Sci. 88: 7605-7609.

Scharer, E. and R. Iggo. 1992. Mammalian p53 can function as a transcription factor in yeast. Nucleic Acids Res. 20: 15391545.

Scheffner, M., B.A. Werness, J.M. Hulbregste, A.J. Levine, and P.M. Howley. 1990. The E6 protein encoded by human papillomavirus types 16 and 18 promotes the degradation of p53. Cell 63: 1129-1136.

Shaulsky, G., N. Goldfinger, M.S. Tosky, A.J. Levine, and V. Rotter. 1991. Nuclear localization is essential for the activity of p53 protein. Oncogene 6: 2055-2065.

Srivastava, S., Z.Q. Zou, K. Pirollo, W. Blattner, and E.H. Chang. 1990. Germ-line transmission of a mutated p53 gene in a cancer-prone family with Li-Fraumeni syndrome. Nature 348: $747-749$. 
Stenger, J., G.A. Mayr, K. Mann, and P. Tegtmeyer. 1992. Formation of stable p53 homotetramers and multiples of tetramers. Mol. Carcinog. 5: 102-106.

Sturzbecher, H.R. Brain, T. Maimets, C. Addison, K. Rudge, and J.R. Jenkins. 1988. Mouse p53 blocks SV40 DNA replication in vitro and downregulates $\mathrm{T}$ antigen DNA helicase activity. Oncogene 3: 405-413.

Tooze, J. (ed.) 1981. Molecular biology of tumor viruses: DNA tumor viruses, 2nd ed. Cold Spring Harbor Laboratory, Cold Spring Harbor, New York.

Unger, T., M.M. Nau, S. Segal, and J.D. Minna. 1992. p53: A transdominant regulator of transcription whose function is ablated by mutations occurring in human cancer. EMBO $\mathrm{I}$. 11: 1383-1390.

Wang, E.H., P.N. Friedman, and C. Prives. 1989. The murine p53 protein blocks the replication of SV40 DNA in vitro by inhibiting the initiation functions of SV40 large $\mathrm{T}$ antigen. Cell 57: 379-392.

Weintraub, H., S. Hauschka, and S.J. Tapscott. 1991. The MCK enhancer contains a p53 responsive element. Proc. Natl. Acad. Sci. 88: 4570-4571.

Wilcox, D. and D.P. Lane. 1991. Localization of p53, retinoblastoma and host replication proteins at sites of viral replication in herpes-infected cells. Nature 349: 429-431.

Yew, P.R. and A. Berk. 1992. Inhibition of p53 transactivation required for transformation by adenovirus early $1 \mathrm{~B}$ protein. Nature 357: 82-85.

Yewdell, J.W., J.V. Gannon, and D.P. Lane. 1986. Monoclonal antibody analysis of p53 expression in abnormal and transformed cells. J. Virol. 59: 444-452.

Zambetti, G.P., J. Bargonetti, K. Walker, C. Prives, and A.J. Levine. 1992. Wild-type p53 mediates positive regulation of gene expression through a specific DNA sequence element. Genes \& Dev. 6: 1143-1152.

Zhu, J., M. Abate, P.W. Rice, and C. Cole. 1991. The ability of simian virus 40 large $T$ antigen to immortalize primary mouse embryo fibroblasts cosegregates with its ability to bind to p53. I. Virol. 65: 6872-6880.

Zhu, J., P.W. Rice, L. Gorsch, M. Abate, and C. Cole. 1992. Transformation of a continuous rat embryo fibroblast cell line requires three separate domains of simian virus 40 large T antigen. I. Virol. 66: 2780-2791. 


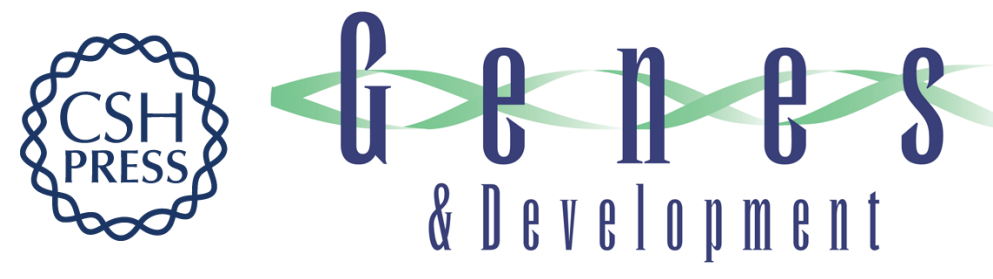

\section{Site-specific binding of wild-type p53 to cellular DNA is inhibited by SV40 T antigen and mutant p53.}

J Bargonetti, I Reynisdóttir, P N Friedman, et al.

Genes Dev. 1992, 6:

Access the most recent version at doi:10.1101/gad.6.10.1886

References This article cites 61 articles, 31 of which can be accessed free at:

http://genesdev.cshlp.org/content/6/10/1886.full.html\#ref-list-1

License

Email Alerting Receive free email alerts when new articles cite this article - sign up in the box at the top Service right corner of the article or click here.

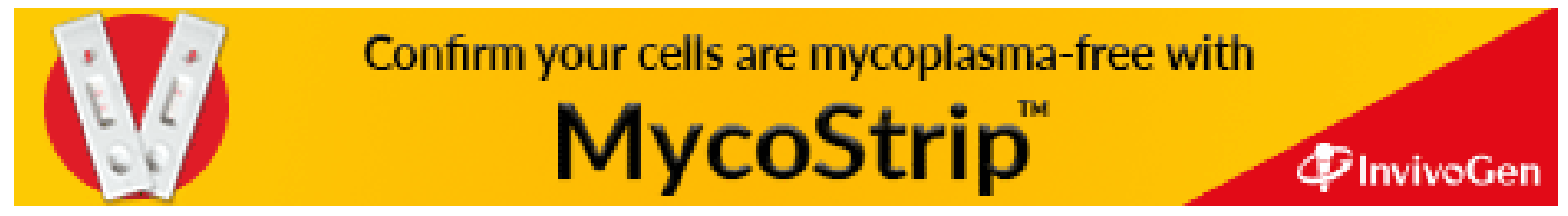

